\section{Н.И. Гаврилова*}

\section{Александра Ксенофонтовна} Медведникова: материалы к

биографии (к вопросу изучения динамики моделей

благотворительной деятельности женщин купеческого сословия XIX - начала XX в.)

DOI: $10.31518 / 2618-9100-2019-3-3$

УДК 94(571.1)

Выходные данные для цитирования:

Гаврилова Н.И. Александра Ксенофонтовна Медведникова: материалы к биографии (к вопросу изучения динамики моделей благотворительной деятельности женщин купеческого сословия XIX - начала XX в.) // Исторический курьер. 2019. № 3 (5). Статья 3. URL: http://istkurier.ru/data/2019/ISTKURIER-20193-03.pdf

\section{N.I. Gavrilova*}

Alexandra Ksenofontovna

Medvednikova: Materials for the

Biography (On the Issue of Studying

Dynamics of Patterns of Charitable

activity of Merchant Class Women in the

$19^{\text {th }}-$ early $20^{\text {th }}$ century)

DOI: 10.31518/2618-9100-2019-3-3

How to cite:

Gavrilova N.I. Alexandra Ksenofontovna Medvednikova: Materials for the Biography (On the Issue of Studying Dynamics of Patterns of Charitable activity of Merchant Class Women in the $19^{\text {th }}$ - early $20^{\text {th }}$ century) // Historical Courier, 2019, \# 3 (5). Article 3. [Available online:] http://istkurier.ru/ data/2019/ISTKURIER-2019-3-03.pdf

Abstract. The article is devoted to the study of the biography of A.K. Medvednikova, a representative of Irkutsk merchant families of Sibiryakovs and Medvednikovs. Charitable activity of A.K. Medvednikova is considered as a manifestation of one of the gender and generational models of philanthropy of the $19^{\text {th }}$ century. It was typical for women of the merchant class of the age cohort born in the 1810-1820s. Representatives of this generational cohort were among the first to actively engage in social activities related to charity. The analysis of Medvednikova's motivation and forms of participation in charitable activities is carried out taking into account the characteristics of her age, family, educational and economic status, value orientations. The role of charity family traditions and the depth of religious attitudes are emphasized. It is proved that the active work of her husband, merchant of the 1st Guild I.L. Medvednikov in the public arena, created the opportunity to expand the public sphere of activity for Alexandra Ksenofontovna.

On the basis of archival materials introduced into scientific circulation, the autor considers the main features of the lifestyle of the Medvednikov married couple in Irkutsk and Moscow; reveals the conditionality of Church charity priorities of Medvednikovs in Moscow and the peculiarities of the Medvednikovs' relationship with the Siberian Association, including the Irkutsk merchants who moved to Moscow in the middle - second half of the $19^{\text {th }}$ century. The author analizes reasons for which the Medvednikovs' membership in Moscow charitable societies (including the "Society for the help to Siberian Paris in Miscow") was only nominal. Considerable attention is paid to the analysis of the A.K. Medvednikova's bequest. According to this bequest, more than 5 million rubles were donated to various charitable needs. The specificity of A.K. Medvednikovs' bequest in favor of the Irkutsk self-government is emphasized. This bequest was one of the few examples of close cooperation between the donor and municipal authorities in the appointment of bequeathed capital. The author comes to conclusion that A.K. Medvednikova implemented a member of "women's charity" typical of her generation.

Keywords: gender; charity; merchants; donations by bequest; Medvednikovs; Sibiryakovs; Irkutsk; Moscow.

\footnotetext{
* Гаврилова Наталья Игоревна, кандидат исторических наук, доцент кафедры социологии и психологии, Иркутский национальный исследовательский технический университет (Иркутск, Россия), е-таil: nig2312@yandex.ru

Gavrilova Natalya Igorevna, Candidate of Historical Sciences, Associate Professor, Department of Sociology and Psychology, Irkutsk National Research Technical University (Irkutsk, Russia), e-mail: nig2312@yandex.ru
} 
The article has been received by the editor on 30.01.2019.

Full text of the article in Russian and references in English are available below.

\begin{abstract}
Аннотация. Статья посвящена исследованию биографии А.К. Медведниковой, представительницы иркутских купеческих родов Сибиряковых и Медведниковых. Благотворительная деятельность А.К. Медведниковой рассматривается в качестве проявления одной из гендерных и поколенческих моделей филантропии XIX в., свойственной женщине купеческого сословия возрастной когорты родившихся в 1810-1820-х гг. Именно представительницы данной поколенческой когорты одними из первых начали достаточно активно осваивать пространство общественно значимой, публичной деятельности, связанной с благотворительностью.
\end{abstract}

Анализ мотивационных установок, форм и характера участия А.К. Медведниковой в благотворительной деятельности, сфер вложения жертвуемых ею капиталов проводится с учетом характеристик ее возрастного, семейного, образовательного и экономического статуса, ценностных ориентаций. Подчеркивается роль семейных традиций благотворительности и глубина религиозных установок. Доказывается, что активная, получающая признание деятельность мужа - купца 1-й гильдии И.Л. Медведникова - на общественном поприще создавала возможность расширения публичной сферы деятельности и для Александры Ксенофонтовны. На основе архивных материалов рассматриваются основные черты образа жизни четы Медведниковых в Иркутске и Москве. Выявлена обусловленность приоритетов церковной благотворительности Медведниковых в Москве, рассмотрены особенности взаимоотношений Медведниковых с сибирской колонией (землячеством) и входящими в нее иркутскими купцами, переехавшими в Москву в середине - второй половине XIX в. Проанализированы причины номинального членства Медведниковых в благотворительных обществах Москвы, в том числе «Обществе вспомоществования учащимся в Москве сибирякам и сибирячкам».

Значительное внимание уделено анализу завещания А.К. Медведниковой, согласно которому на различные благотворительные нужды жертвовалось более 5 млн руб. Подчеркнута специфика принятия А.К. Медведниковой завещательных распоряжений в пользу Иркутского городского общественного самоуправления, ставших одними из немногочисленных примеров тесного взаимодействия жертвователя с муниципальными органами по вопросам назначения завещаемых капиталов. Делается вывод о реализации А.К. Медведниковой типичной для ее поколения модели «женской благотворительности».

Ключевые слова: гендер; благотворительность; купечество; пожертвования по завещанию; Медведниковы; Сибиряковы; Иркутск; Москва.

За последние десятилетия исследование истории благотворительности сибирского купечества уверенно вошло в число активно разрабатываемых сибирскими историками проблем. Традиционным стало обращение к анализу благотворительной деятельности купечества при изучении его социально-психологических характеристик, участия предпринимательских слоев в общественной и культурной жизни города, изучении сферы гражданских инициатив, выражения разнообразных общественных настроений ${ }^{1}$. Важным

\footnotetext{
${ }^{1}$ Очерки историографии Сибири эпохи империи (XVIII - начало XX века) / Л.М. Дамешек, И.Л. Дамешек, В.П. Шахеров, А.С. Маджаров, Т.А. Перцева. Иркутск, 2017. С. 110-113; Бойко В.П. Купечество Западной Сибири в конце XVIII - XIX в.: Очерки социальной, отраслевой и ментальной истории. Томск, 2009. С. 147-225; Шахеров В.П. Социокультурные процессы в городской среде Байкальской Сибири XVIII - первой половине XIX в. Иркутск, 2013. С. 142-233; Комлева E.B. «Тузы-капиталисты»: образ сибирского купца в региональной периодической печати второй половины XIX в. // Известия Иркутского государственного университета. Серия: История. 2018. Т. 24. С. 36-45; Скубневский В.А. Благотворительность предпринимателей Алтая во второй половине XIX - начале XX в. // Вестник Томского государственного университета. 2018. № 435. С. 155-160.
} 
аспектом заявленной проблематики выступает анализ гендерных характеристик благотворительной деятельности сибирского купечества. Актуальным представляется изучение динамики моделей участия женщин, представительниц купеческого сословия, в сфере благотворительности на протяжении XIX - начала XX в. (в том числе изучение мотивационных установок, форм и характера участия в благотворительной деятельности, сфер вложения жертвуемых капиталов), исследование возрастного, семейного, образовательного, экономического статуса женщин-благотворительниц, их происхождения, типичного жизненного сценария, региональных особенностей их благотворительной деятельности.

Осмысление данного круга проблем видится не только на уровне обобщения указанных параметров и их последующей типизации, но и на уровне персонификации, изучения судеб отдельных представительниц купеческого сословия, ярко обозначивших себя в сфере благотворительности.

Данная статья представляет попытку реконструкции биографии А.К. Медведниковой, представительницы крупных купеческих родов Иркутска Сибиряковых и Медведниковых, первой из иркутских благотворительниц удостоенной звания почетной гражданки города Иркутска.

Отдельные биографические сведения о А.К. Медведниковой и ее благотворительной деятельности нашли отражение на страницах обобщающих исследований по истории российской благотворительности ${ }^{2}$, в биобиблиографических справочниках, посвященных истории московского и сибирского купечества ${ }^{3}$. Однако информация отличается фрагментарностью.

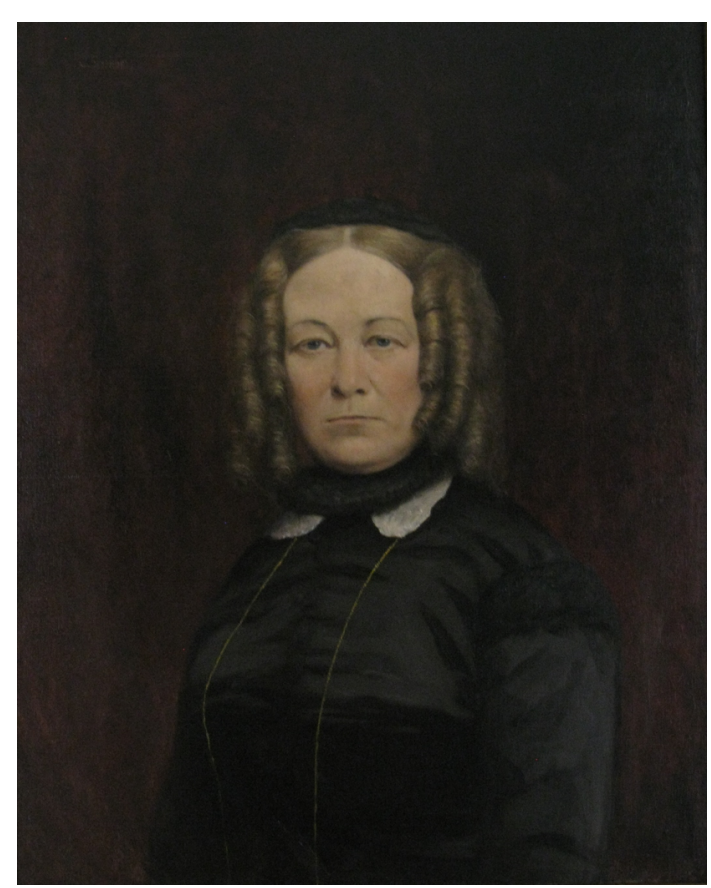

Александра Ксенофонтовна Медведникова, в девичестве Сибирякова.

С картины худ. С.С. Егорнова. Конеи ХІХ в.

Александра родилась 20 января $1814 \Gamma^{4}{ }^{4}$ в семье, принадлежавшей к элите делового мира Иркутска начала XIX в. Ее отец, Ксенофонт Михайлович (1772-24.05.1825), иркутский купец 1-й гильдии, представитель четвертого поколения Сибиряковых, успешно вел коммерческие дела семьи, сумел сохранить ведущее положение фамилии в рамках городского сообщества. Трижды, с 1817 по 1825 г., он служил по выборам городским головой. Александре шел 12-й год, когда, заболев чахоткой, ее отец скончался в возрасте 53 лет.

Во главе семьи встала мать Александры Наталья Дмитриевна (1786-1834/35). Немногочисленные факты ее биографии позволяют судить о ней как сильном и волевом человеке. Пожалуй, она стала первой в купеческой фамилии Сибиряковых женщиной, заявившей о себе как самостоятельной личности. В 40 лет, оставшись вдовой и унаследовав дела мужа, она фактически возглавила семейный «бизнес». Последующие пять лет Наталья Дмитриевна, записываясь «иркутской 1-й гильдии купеческой женой, вдовой», а затем «коммерции советницей» ${ }^{5}$, вместе с братьями умершего мужа, Александром и Петром, вела активную предпринимательскую деятельность, нанимала приказчиков, заключала договора по

\footnotetext{
${ }^{2}$ Ульянова Г.Н. Благотворительность в Российской империи, XIX - начало XX века. М., 2005. С. 159, 247.

${ }^{3}$ Ульянова Г.Н. Благотворительность московских предпринимателей. 1860-1914. Словарь купцовблаготворителей. М., 2014; Зуева Е.А., Гаврилова Н.И. Медведниковы // Энциклопедический словарь по истории купечества и коммерции Сибири. Новосибирск, 2013. Т. 2. С. 37.

${ }^{4}$ Государственный архив Иркутской области (ГАИО). Ф. 156. Оп. 1. Д. 22. Л. 94.

${ }^{5}$ ГАИО. Ф. 70. Оп. 1. Д. 1574. Л. 1-2.
} 
перевозке товаров из Кяхты. Выполняя духовное завещание мужа, вела строительство Никольской церкви на Байкале, занималась внутренней отделкой семейного особняка на Набережной Ангары.

В этом доме, ставшем своеобразным символом богатства и величия купцов Сибиряковых, и прошло детство Александры Ксенофонтовны. Широко известное описание особняка, оставленное побывавшим в Иркутске в 1824 г. А.И. Мартосом ${ }^{6}$, вместе с тем являлось зарисовкой домашней обстановки, окружавшей Александру.

Согласно имеющимся в литературе данным ${ }^{7}$, в семье Ксенофонта Михайловича и Натальи Дмитриевны родилось трое сыновей и шесть дочерей. Из сестер Александры Ксенофонтовны, перешагнувших порог совершеннолетия, сохранились сведения об Анне, вышедшей замуж за иркутского купца Кузнецова, и Марии (1817-1860-е), обвенчанной в конце 1830-х - начале 1840-х гг. с кяхтинским купцом, золотопромышленником Христофором Хрисанфовичем Кандинским (1813-1890). Родные братья Александры Ксенофонтовны, в том числе Николай и Андриан, ушли из жизни молодыми людьми, перечеркнув возможность продолжения родовой веточки Ксенофонта Михайловича Сибирякова по мужской линии.

Вместе с тем в семье воспитывался купленный Ксенофонтом Михайловичем на Ирбитской ярмарке калмыкский мальчик Риспанд (в крещении Александр). Получив права родного сына и распорядителя по дому и коммерческим делам, Александр Ксенофонтович (1790-е - 1868) в 1840-х гг. станет самостоятельным купцом 1-й гильдии, получит потомственное почетное гражданство $\left(1864\right.$ г.). Пройдут годы, и в своем завещании ${ }^{8}$ Александра Ксенофонтовна, следуя христианской традиции, среди имен умерших родственников, перечисленных с просьбой «производить их вечное поминовение», назовет Александра Ксенофонтовича и его супругу Парасковью Петровну (ум. 1864).

Пожалуй, из всех родных братьев и сестер именно Александра Ксенофонтовна сумела в большей степени унаследовать твердый и решительный характер своих родителей, став наиболее яркой представительницей нисходящих поколений этой родовой ветки Сибиряковых. Не случайно современники характеризовали ее как одаренную «недюжинным умом и крепкой волей» ${ }^{9}$ и неизменно подчеркивали полученное ею «прекрасное образование» ${ }^{10}$.

Его азы были получены в рамках домашнего обучения, вероятно, у частных учителей. Еще в 1809 г. в Иркутске педагогической практикой занимались 23 человека, у которых обучались 116 мальчиков и 19 девочек, главным образом, из семей представителей администрации края, крупнейших иркутских и иногородних купцов. Богатой была и домашняя библиотека, составленная отцом и дедом, - одно из первых крупных частных собраний города в купеческой среде. Коллекции картин и гравюр способствовали развитию художественного вкуса. Тягу к образованию, поражавшую современников, Александра Ксенофонтовна сохранит на всю жизнь.

Чрезвычайно важным аспектом образования выступало религиозно-нравственное воспитание. Следование нормам религиозного благочестия, соблюдение религиозных обрядов и традиций высоко ценилось в купеческой среде. Яркие примеры соответствующего поведения были усвоены Александрой Ксенофонтовной с детства. Ее родная тетка Агриппина Михайловна, приняв постиг с именем Августы, стала игуменьей Знаменского женского монастыря. Ее единственную из всех многочисленных братьев и сестер своего отца Александра Ксенофонтовна упомянет в своем завещании ${ }^{11}$.

\footnotetext{
${ }_{6}^{6}$ Мартос А.И. Письма из Восточной Сибири. М., 1827. С. 153-154.

${ }^{7}$ Душкин Ю. «...от корабельного морского ходу» // Литературный Иркутск. 1989. Март. С. 14-15.

${ }^{8}$ Известия Иркутской городской думы. 1898. № 3-4. С. 107.

${ }^{9}$ Гимназия Медведниковых // Сибирская жизнь. 1901. № 225. С. 3.

${ }^{10}$ Там же.

${ }^{11}$ Памяти умершей благотворительницы Александры Ксенофонтовны Медведниковой // Церковные ведомости. 1900. № 13. 25 марта. С. 542.
} 
Глубоко усвоенными Александрой Ксенофонтовной с детства оказались уроки христианской благотворительности и пожертвований на храмы. Александре было 6 лет, когда под руководством ее отца, городского головы К.М. Сибирякова началось строительство Входо-Иерусалимской церкви (1820 г.). Среди жертвователей на этот храм значилась и мать Александры - Наталья Дмитриевна.

Религиозным обетом для Ксенофонта Михайловича Сибирякова и нравственным долгом для его наследников - прежде всего вдовы Натальи Дмитриевны, а впоследствии для самой Александры Ксенофонтовны стало возведение Усть-Морской Никольской церкви в с. Лиственичное на Байкале. Все эти храмы, включая приходскую для Сибиряковых Тихвинскую церковь Иркутска, станут в дальнейшем объектами постоянного внимания и пожертвований Александры Ксенофонтовны. Пожертвования в пользу церкви, в целом, займут доминирующее значение в ее благотворительной деятельности.

Подобные приоритеты, безусловно, имели и объективные основания. В условиях господствующих представлений относительно общественного предназначения женщины как матери и хранительницы домашнего очага одним из немногих социально одобряемых каналов выхода женщины из приватной сферы в публичную и, более того, общественно значимую, начинает осознаваться благотворительность, причем, в ее наиболее традиционных формах пожертвований на нужды церкви, в пользу сирых и убогих. Подобная благотворительность воспринималась как логическое продолжение акта церковного богослужения. Она органично сочеталась с представлением о роли женщины в обществе, соответствовала взглядам о ее набожности и приверженности христианским добродетелям.

Пожалуй, первой поколенческой когортой женщин купеческого сословия Иркутска, начавшей осваивать пространство общественно значимой, публичной деятельности, стала когорта родившихся в 1810-1820-х гг. Уже в середине XIX в. в сфере благотворительности обозначат себя ряд представительниц, прежде всего, крупных купеческих родов Иркутска: Александра Никаноровна Портнова (1813/14-1890, урожденная Трапезникова), Олимпиада Филипповна Мыльникова (1810/15-1905, урожденная Трапезникова), Анна Прокопьевна Мичурина (1815 - после 1869, урожденная Медведникова), Зинаида Ивановна Трапезникова (около 1820-х 1877 ; происхождение неизвестно, жена купца 1-й гильдии К.П. Трапезникова) $)^{12}$. Одной из наиболее заметных представительниц данной поколенческой когорты женщин купеческого сословия Иркутска в сфере благотворительной деятельности 40-90-х гг. XIX в. стала Александра Ксенофонтовна.

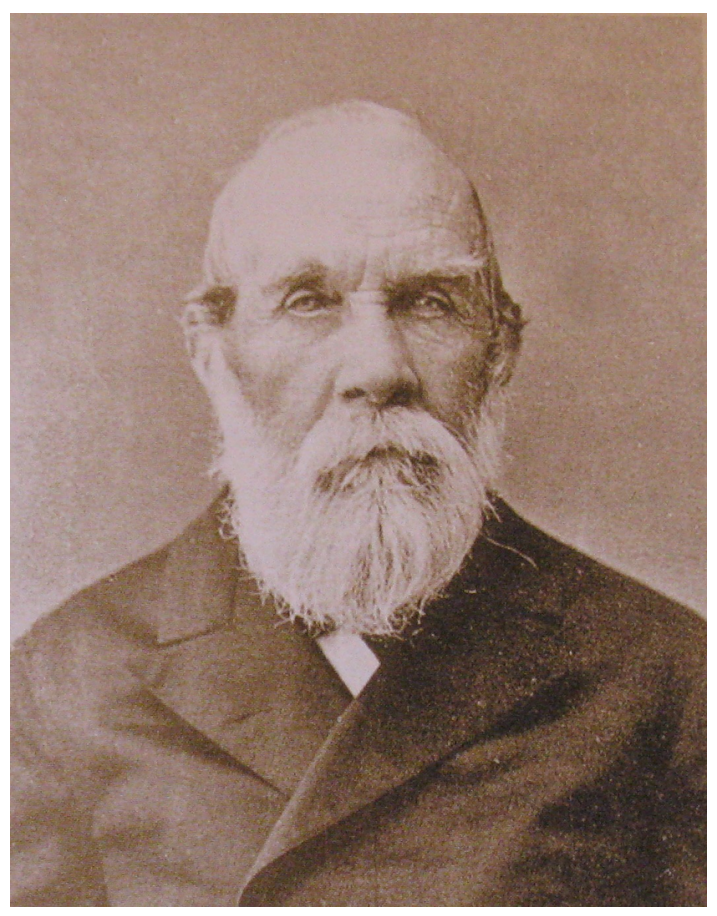

Иван Логинович Медведников, иркутский купеи 1-й гильдии. Фото 1880-е г2.

В 1829 г. 16-летняя Александра Ксенофонтовна была обвенчана с иркутским купцом 1-й гильдии Иваном Логиновичем Медведниковым (9.11.1807-1.09.1889). Выбор был сделан не случайно. И.Л. Медведников неоднократно упоминается во второй половине 1820 -х гг. среди коммерческих партнеров Н.Д. Сибиряковой. Вероятно, Наталья Дмитриевна, как мать, находила такую «партию» для дочери весьма перспективной, обеспечивающей ее будущее. «Расчет» оправдался. Иван Логинович примет на себя ответственность за строительство Никольской церкви на Байкале. В 1835 г. на правах попечителя он вместе с купцами

\footnotetext{
${ }^{12}$ Гаврилова Н.И., Ермолаев А.Н., Зуева Е.А., Разгон В.Н. Мыльниковы // Энциклопедический словарь... Т. 2. С. 73; Гаврилова Н.И. Портнова // Там же. С. 181; Милютин Б.А. Генерал-губернаторство Н.Н. МуравьеваАмурского в Сибири // Исторический вестник. 1888. № 12. С. 625.
} 
П. Саламатовым и С. Сумкиным оплатит все долги скончавшейся в Москве в 1834/35 г. Натальи Дмитриевны.

Иван Логинович принадлежал к четвертому поколению иркутских купцов Медведниковых, переселившихся в Иркутск, как и Сибиряковы, в 1720-х гг. из Архангелогородской губернии. Уже представители второго поколения Медведниковых заявляют о себе как состоятельные купцы. Третье поколение вывело Медведниковых в первостатейное купечество региона. Братья Иван, Логин (1773-1814) и Прокопий (1774 около 1843) Федоровичи входили в число богатейших предпринимателей, ведущих крупную торговлю в Кяхте. Медведниковы были заметны и в сфере городского самоуправления, благотворительных начинаний. В 1814-1817 гг. Прокопий Федорович Медведников, родной дядя Ивана Логиновича, исполнял должность городского головы.

Ивану было 7 лет, когда умер его отец - иркутский купец 1-й гильдии Логин Федорович Медведников. Воспитанием сыновей, Ивана и Логина, занималась их мать Елизавета Михайловна (в девичестве Красногорова). Достигнув совершеннолетия, в 1824 г., 17-летний И.Л. Медведников, освободившись от опеки, повел коммерческие дела самостоятельно, объявляя капитал по 1-й гильдии. Через 10 лет (в 1834 г.) получил звание потомственного почетного гражданина ${ }^{13}$. Подтверждением успешности ведения торговых операций и стабильно высоких оборотов стало пожалование в 1839 г. 32-летнему Ивану Логиновичу чина коммерции советника ${ }^{14}$. В течение всей жизни И.Л. Медведников сохранял высокую деловую репутацию, ни разу не выйдя из состава первостатейного купечества. Основными сферами вложения капитала выступала «торговля заграничная в Кяхте, внутренний гуртовой торг в Иркутске, Москве, Макарьевской, Ирбитской и Якутской ярмарках» ${ }^{15}$. Только в Иркутске в течение 1830-х гг. им было приобретено 45 «частей» в купеческом гостином дворе и 6 - в мещанском ${ }^{16}$. Обмен сибирской пушнины на китайские товары и реализация их на крупнейших ярмарках страны, а также в розницу на сибирских рынках являлась одним из основных источников накопления капиталов, позволив со временем составить состояние в 7 млн руб. ${ }^{17}$

Брак с Александрой Ксенофонтовной Сибиряковой был заключен И.Л. Медведниковым в 1829 г., год спустя после смерти матери, Елизаветы Михайловны (1787-1828). К этому времени Иван Логинович уже крепко стоял на ногах, располагая не только крупным торговым капиталом, но и влиятельными связями в Петербурге. В 1829 г. он был избран в действительные члены Общества любителей коммерческих знаний при Московской практической коммерческой академии, попечительский совет которой возглавлял московский военный генерал-губернатор князь Д.В. Голицын. Среди членов Общества, в котором И.Л. Медведников пробыл 10 лет, значились князь А.А. Долгорукий, граф К.В. Нессельроде, граф А.А. Аракчеев, М.М. Сперанский и другие видные современники. Безусловно, членство в столь высокостатусном Обществе было престижно.

В Иркутске же первой для Ивана Логиновича общественной службой по выбору стала должность церковного старосты Тихвинской (Воскресенской) церкви (1830-1833гг. ${ }^{18}$. С этого же времени заметной становится и его благотворительная деятельность. Одно из первых крупных пожертвований - дар в 2300 руб. Тихвинской церкви «на серебряную под золотом ризу на образ Св. Апостола Иоанна Богослова» ${ }^{19}$. Этот храм особо выделялся И.Л. и А.К. Медведниковыми: долгие годы церковь являлась для Сибиряковых приходской.

Однако предметом особого внимания в 1830-1840-х гг. для Ивана Логиновича стало его деятельное участие в подготовке к открытию в Иркутске Сиропитательного дома для

\footnotetext{
${ }^{13}$ ГАИО. Ф. 156. ОП. 1. Д. 22. Л. 93 об.

${ }^{14}$ Там же. Л. 94 об.

${ }^{15}$ Там же. Л. 94.

${ }^{16}$ Там же. Л. 94-95.

${ }^{17}$ Шахеров В.П. Иркутск купеческий. Хабаровск, 2006. С. 89.

${ }^{18}$ ГАИО. Ф. 156. ОП. 1. Д. 22. Л. 93 об.

${ }^{19}$ Там же. Л. 28.
} 
девочек на средства, завещанные для этой цели ему и брату Логину их матерью Е.М. Медведниковой.

Рассмотрение вопроса в Петербурге заняло несколько лет. Только 20 июня 1836 г. вышло «Положение о Сиропитательном доме в Иркутске и частном при нем банке» ${ }^{20}$. Данное учреждение положило начало школьному обучению девочек в Восточной Сибири, став первым подобным заведением в регионе.

Уже через год - 13 мая 1837 г. - «в деревянном доме почетного гражданина Ивана Логиновича Медведникова открыт заемный банк в пользу учреждаемого им Сиропитательного дома для малолетних девиц. Банк должен состоять под председательством иркутского градского губернатора и градского головы и самого основателя заведения оного, как непременного члена или хозяина, Ивана Логиновича Медведникова. А от общества должны избираться на каждое 3-летие по два члена и по ним два кандидата» ${ }^{21}$. Спустя всего месяц, 12 июня в Иркутске «против церкви Преображения Господня с северной стороны заложено новое каменное здание собственным иждивением почетных граждан иркутских 1 гильдии купцов Ивана и Логина Логиновичей Медведниковых для Сиропитательного дома бедных девиц» ${ }^{22}$ В том же 1837 году 23-летняя А.К. Медведникова совершит сделку по продаже семейного особняка Сибиряковых казне.

В 1840 г. здание Сиропитательного дома было построено. К этому времени он уже функционировал. На основе предоставленных в Петербург первых двух годовых отчетов деятельность Попечительного совета была признана успешной, а И.Л. Медведников удостоен «Высочайшего благоволения Е.И.В. Государыни Императрицы» ${ }^{23}$.

Признанием трудов И.Л. Медведникова по открытию и деятельности Сиропитательного дома стало пожалование ему золотой медали «За полезное» на Анненской ленте (1836 г.) и «соизволение Е.И.В. Государыни Императрицы на личное с женою представление к Ея Величеству в четверток на Святой неделе 18 апреля 1840 г.» ${ }^{24}$. 26-летняя Александра Ксенофонтовна стала одной из первых купеческих жен Иркутска, удостоенной столь высокой чести. Мы не располагаем сведениями о ее возможном участии в делах мужа как учредителя и попечителя Сиропитательного дома. Однако его активная, получающая признание деятельность на общественном поприще создавала возможность расширения публичной сферы деятельности и для Александры Ксенофонтовны.

К концу 1830-х - началу 1840-х гг. относятся и первые известные нам крупные пожертвования А.К. Медведниковой. Ими стали внесенные совместно с мужем средства на строительство и содержание Усть-Морской Никольской на Байкале (2 тыс. руб. серебром) и иркутской Входо-Иерусалимской церквей. История возникновения этих храмов была тесно связана с семьей Сибиряковых: попечение об объектах «семейной благотворительности» воспринималось четой Медведниковых в качестве нравственного долга. За пожертвования в пользу этих церквей Александра Ксенофонтовна вместе с мужем в 1844 г. была удостоена «искреннейшей благодарности» архиепископа Нила ${ }^{25}$.

Принадлежность Ивана Логиновича Медведникова к деловой элите предпринимательского мира Иркутска обеспечивали его супруге высокие статусные позиции в местном обществе. К началу 1840-х гг. Александра Ксенофонтовна являлась потомственной почетной гражданкой, коммерции советницей, женой городского головы (в 1841-1844 гг. И.Л. Медведников служил по выборам городским головой) ${ }^{26}$, иркутского купца 1-й гильдии, чья благотворительная деятельность была отмечена на Высочайшем уровне. Иван Логинович имел две золотые медали «За полезное» на Анненской (1836 г.) и

\footnotetext{
${ }^{20}$ ПСЗ РИ. Собр. 2. СПб., 1833. Т. ХІ. № 9332. С. 741-747.

${ }^{21}$ Кротов В.А. Летопись города Иркутска. 1652-1856 гг. Иркутск, 2013. С. 162.

${ }^{22}$ Там же. С. 163.

${ }^{23}$ ГАИО. Ф. 156. ОП. 1. Д. 22. Л. 95 об.

${ }^{24}$ Там же. Л. 96 об.

${ }^{25}$ Там же. Л. 99 об.

${ }^{26}$ Там же. Л. 97 об.
} 
Андреевской (1845 г.) лентах, в 1847 г. был награжден орденом Святой Анны 3-й степени ${ }^{27}$. Согласно утвержденному в 1845 г. «Уставу Иркутского Сиропитательного дома Е. Медведниковой и учрежденного при нем банка», он был утвержден в звании «почетного члена Совета Сиропитательного дома и банка при нем с правом присутствовать в Совете и носить мундир, присвоенный заведениям Е.И.В. VII разряда» ${ }^{28}$. Современники характеризовали его в эти годы как довольного молодого, красивого, вежливого и умного человека ${ }^{29}$.

На вечерах, устраиваемых Александрой Ксенофонтовной в своем доме, собиралось, по словам современников, «прекрасное общество, состоявшее из сенаторской молодежи и многих из здешнего высшего общества» ${ }^{30}$. Гостями в доме Медведниковых были и путешественники - как отечественные, так и иностранные. Об одном из таких вечеров очевидец писал: «...вернулся я домой только полпервого. Сильнее всего этот вечер украсил своим пением господин Сиверс. Его красивый и необычно сильный голос по-настоящему проявился только там, в огромном зале при прекрасном фортепьяно» ${ }^{31}$.

Отличала Александру Ксенофонтовну и постоянная тяга к образованию. В течение двух с половиной лет (1844-1846 гг.) она брала уроки итальянского и немецкого языков у Юлиана Гляубича Сабиньского, польского ссыльного, участника польского восстания 1830-1831 гг., в 1843 г. переведенного на поселение. О первой встрече с Александрой Ксенофонтовной Ю.Г. Сабиньский писал: «Богатая сама и имеющая богатого мужа, она хотела бы потратить значительную часть имущества на то, чтобы посмотреть мир, и через год или два она собирается ехать в Германию, Италию и Францию, поэтому хочет выучить иностранные языки» ${ }^{32}$.

Довольно тесные отношения связывали Медведниковых с иркутской колонией декабристов. Трубецкие, Волконские, Поджио, Муравьевы нередко посещали вечера гостеприимной хозяйки, «запросто» бывали в доме Медведниковых. «Давним знакомым» Александры Ксенофонтовны называл Сабиньский на страницах своего дневника Иосифа Викторовича Поджио. Александра брала у него уроки игры на фортепьяно. А старший брат, Александр Викторович Поджио, преподавал ей французский ${ }^{33}$.

В свою очередь чета Медведниковых бывала в домах декабристов, посещала вечера Волконских, собиравших цвет тогдашнего иркутского общества. Нередко Александра Ксенофонтовна составляла компанию в их загородных прогулках, в том числе в местечке близ Иркутска под названием «Камчатник». О «свободных, без каких-либо натянутостей разговорах, вкусной трапезе и прогулках при прекрасной погоде в окружении семьи Трубецких, нескольких товарищей по изгнанию и нескольких наиболее близких знакомых из города, в т. ч. губернаторши Пятницкой и госпожи Медведниковой» Ю. Сабиньский не раз упоминал на страницах своего дневника ${ }^{34}$.

Светскость и образованность Александры Ксенофонтовны сочетались в ней с глубокой религиозностью, строгим исполнением обрядов. «Начав в четыре часа свое Пасхальное богослужение, почти весь день провела в церкви», - напишет о А.К. Медведниковой Ю. Сабиньский в Пасхальные дни 1845 г. ${ }^{35}$

Вопрос о переезде в Москву на постоянное жительство и переносе в столицу коммерческих дел являлся для четы Медведниковых в 1845 г. уже решенным. В 1848 г. Иван Логинович и Александра Ксенофонтовна уже проживали в Петербурге ${ }^{36}$. Пробыв в северной

\footnotetext{
${ }^{27}$ ГАИО. Ф. 156. ОП. 1. Д. 22. Л. 99 об, 101.

${ }^{28}$ Там же. Л. 99 об.

${ }^{29}$ Сабиньский Ю.Г. Сибирский дневник. Иркутск, 2015. Т. 2. С. 135.

${ }^{30}$ Там же. С. 227.

${ }^{31}$ Там же.

${ }^{32}$ Там же. С. 131.

${ }^{33}$ Там же. С. 131-135.

${ }^{34}$ Там же. С. 185.

${ }^{35}$ Там де. С. 272.

${ }^{36}$ ГАИО. Ф. 156. Оп. 1. Д. 22. Л. 114.
} 
столице непродолжительное время, Медведниковы переехали в Москву, «в которой и оставались до своей смерти, живя в роскошном отдельном собственном доме по СтароКонюшенному переулку» ${ }^{37}$. C XVIII в. эта территория начала застраиваться богатыми домами дворян и позднее стала одним из аристократических районов Москвы. Окончательно обосновавшись в столице, Медведниковы продали дом в Иркутске. В начале 1858 г. в письме к С.П. Трубецкому А.В. Поджио, сообщая иркутские новости, писал: «Медведников продал свой дом, со всем, что в нем есть, за 15000 рублей, и все смеются» ${ }^{38}$.

Лето они обыкновенно проводили в своем имении - в с. Поречье близ Звенигорода. Согласно имеющимся данным, усадьба Поречье, заложенная во второй половине XVIII в. и с тех пор сменившая нескольких хозяев, была приобретена И.Л. Медведниковым в 1870 г. ${ }^{39}$ Новые владельцы построят усадебный дом, церковь, разобьют парк. Их соседями по усадьбе станут чаеторговцы Поповы. Возможно, с Медведниковыми Поповых объединяли и коммерческие интересы.

Однако круг общения Медведниковых в Москве, их приватная и публичная жизнь, сферы предпринимательской активности И.Л. Медведникова, участие в жизни Московского купеческого общества и общественного городского самоуправления пока остаются слабоизученными.

Как отмечали современники, «несмотря на огромное состояние, Медведниковы вели в высшей степени скромную жизнь. Глубоко религиозные, они были врагами всяких излишеств и шумных удовольствий» ${ }^{40}$. Имеющиеся данные подтверждают характеристики об уединенном образе жизни четы Медведниковых в Москве. Среди отрывочных сведений можно выделить следующие, связанные, прежде всего, с их пребыванием в с. Поречье.

В 1855 г. И.Л. Медведниковым на нужды «государственного ополчения и другие военные надобности» было пожертвовано 1000 руб. ${ }^{41}$ В 1870 г. он становится членом Православного миссионерского общества ${ }^{42}$. В 1879-1880 гг. вместе с Александрой Ксенофонтовной оказывает финансовую помощь Звенигородскому комитету Общества Красного Креста ${ }^{43}$. В течение 1880-х гг. неоднократно жертвует на нужды Покровского летнего приюта для бедных детей, находившегося в его Подмосковном имении ${ }^{44}$. В 1887 г. становится действительным членом Общества школьных вакационных колоний в Москве ${ }^{45}$.

Особую значимость для А.К. и И.Л. Медведниковых представляла деятельность, концентрировавшаяся вокруг их приходской церкви Усекновения Главы Иоанна Предтечи в Старой Конюшенной слободе. Александра Ксенофонтовна и Иван Логинович являлись щедрыми жертвователями в пользу приходского храма, принимали участие в открытом в 1872 г. при церкви приходском попечительстве. Уже в 1865 г. Медведниковыми было пожертвовано 5600 руб. на восстановление и украшение церкви ${ }^{46}$. Через 20 лет, к 1885 г., сумма пожертвований возросла до 10759 руб. В знак благодарности священнослужители и прихожане Предтеченской церкви обратились с прошением о награждении И.Л. Медведникова орденом Святой Анны 2-й степени ${ }^{47}$. В 1886 г. Ивану Логиновичу был пожалован орден Святого Станислава 2-й степени ${ }^{48}$.

Доверительные отношения сложились у четы Медведниковых с приходским духовенством - в первую очередь, с настоятелем храма протоиереем Алексеем

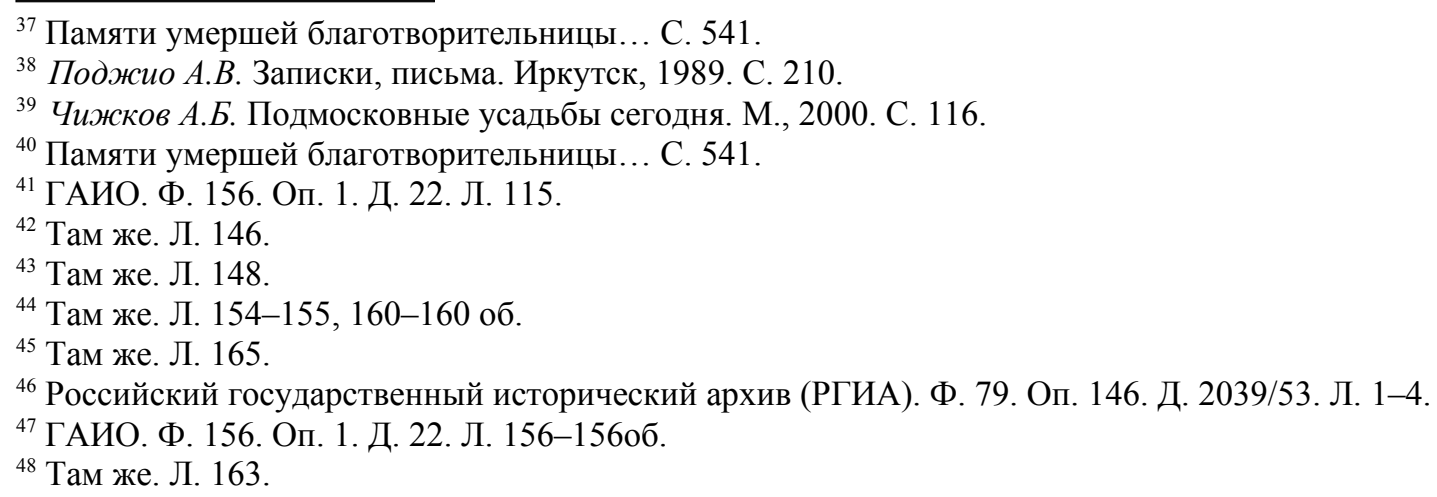


Дмитриевичем Цветковым (1825-1909). Сам священнослужитель в третьем поколении, он являлся духовником священнослужителей Пречистенского сорока (сорок - церковноадминистративная единица в Москве XVI - начала XX в.), был удостоен многих наград, в 1900 г. возведен в дворянское достоинство. Его сына - Николая Алексеевича Цветкова (23.04.1857-15.03.1928), надворного советника, товарища председателя Московского купеческого банка (1900 г.), Александра Ксенофонтовна Медведникова назначит в своем завещании душеприказчиком ${ }^{49}$. Современники же неизменно называли Н.А. Цветкова «старинным другом семьи Медведниковых». Действительно, Николай Алексеевич вырос на глазах Александры Ксенофонтовны. Можно предположить, что, не имея своих детей (сведения о сыне-инвалиде Иване, скончавшемся в 1881 г., нуждаются в уточнении), Александра Ксенофонтовна проявляла особую заботу и внимание к Николаю.

Не были утеряны Медведниковыми и связи с Иркутском. В 1858 г. Александра Ксенофонтовна признавалась: «Желала бы побывать в Иркутске на короткое время [...]. И тянет в Иркутск, и держит Москва» ${ }^{50}$. Имеющиеся в литературе данные свидетельствуют, в целом, о сохранении в качестве значимой ценности у большей части иркутских купцов, переехавших в Москву и Петербург в середине - второй половине XIX в., достаточно тесной соотнесенности с иркутским обществом, важности своего участия в развитии города, главным образом, в рамках благотворительной деятельности.

Этот же канал достаточно активно использовался А.К. и И.Л. Медведниковыми. Однако сформированные ранее, в 1820-40-е гг., приоритеты церковной благотворительности оставались для Александры Ксенофонтовны неизменными и в 1860-1890-е гг. Особой поддержкой А.К. и И.Л. Медведниковых пользовались Тихвинская и Входо-Иерусалимская церкви Иркутска ${ }^{51}$. Откликнулись Медведниковы и на строительство в Иркутске Казанской церкви ${ }^{52}$. Помощь от четы Медведниковых получали церкви и монастыри других городов, в том числе Енисейский женский монастырь ${ }^{53}$.

Для И.Л. Медведникова предметом особого внимания оставался Иркутский сиропитательный дом Е. Медведниковой. В заседании от 27 апреля 1887 г. иркутская городская дума, в связи с 50-летним юбилеем со дня учреждения в Иркутске Сиропитательного дома и «банка при нем», основанных на средства И.Л. Медведникова, постановила ходатайствовать о возведении его в почетные граждане города Иркутска ${ }^{54}$. В ответном письме И.Л. Медведников отмечал: «Я буду по справедливости гордиться тем почетом, каким удостоила меня родина, и, если по обстоятельствам я нахожусь от нее в отдалении, тем не менее, я живо чувствую свою тесную духовную с ней связь» ${ }^{55}$.

В Москве же таким своеобразным центром притяжения выходцев из Восточной Сибири - прежде всего Иркутска - служило «Общество вспомоществования учащимся сибирякам и сибирячкам». Вокруг него группировалась издавна существовавшая в Москве колония сибиряков ${ }^{56}$. Организаторами созданного в 1884 г. Общества выступали Ю.И. Базанова (1852-1924), М.А. Зензинова (р. 1850-е гг.), Е.В. Барановская (1859-1930-е), М.М. Зензинов (1850-1927), Н.В. Баснин (1843-1918), Ф.А. Деньгин (1829-1898). В 1885 г., внеся пожертвования, членом-учредителем Общества стал и И.Л. Медведников ${ }^{57}$. Однако для 77-летнего Ивана Логиновича и 70-летней Александры Ксенофонтовны членство в Обществе осталось номинальным. Можно предположить, что и

\footnotetext{
49 Памяти умершей благотворительницы... С. 543.

${ }^{50}$ Манассеин В.С. Сибирский библиофил В.Н. Баснин и его библиотека (первая половина ХІХ-го ст.). Иркутск, [б.г.]. Фонд Научной библиотеки Иркутского государственного университета. Рукопись № 397. С. 31.

${ }^{51}$ ГАИО. Ф. 156. Оп. 1. Д. 22. Л. 127, 150.

52 Там же. Л. 33, 153.

${ }^{53}$ Там же. Л. 143.

${ }^{54}$ ГАИО. Ф. 70. Оп. 2. Д. 1996. Л. 31-32.

${ }^{55}$ Там же. Л. 33.

${ }^{56}$ Попов И.И. Забытые иркутские страницы. Записки редактора. Иркутск, 1989. С. 308.

${ }^{57}$ ГАИО. Ф. 156. Оп. 1. Д. 22. Л. 159, 161.
} 
сама упомянутая «колония сибиряков», своеобразное иркутское землячество, воспринималось Медведниковыми в 1880-х гг. дистанцированно.

Организаторами и активно действующими членами «Общества вспомоществования...» были представители уже другого поколения, возрастной когорты родившихся в 1840-1850-е гг. Период их взросления пришелся на 1860-1870-е гг., обусловив специфику поведенческих моделей их публичной деятельности, уровень участия в общественной жизни, мотивационные установки благотворительности. Тенденция активного вовлечения женщин, представительниц предпринимательских слоев, в деятельность благотворительных муниципальных институтов и общественных объединений именно с 1880-х гг. была зафиксирована в литературе неоднократно ${ }^{58}$. Однако Александра Ксенофонтовна оставалась представительницей своей, уже ушедшей эпохи середины XIX в.

Для Медведниковых, перебравшихся в Москву в начале 1850-х гг., круг «иркутских знакомых» в тот период составляли немногочисленные семьи иркутских и забайкальских купцов, которые, как и Медведниковы, в конце 1850-х - начале 1860-е гг. переехали в столицу (семьи В.Н. и Е.О. Басниных, А.К. Трапезникова, В.Н. и С.С. Сабашниковых, Н.Х. и М.Н. Кандинских), а также семьи двоюродных братьев и сестер Гавриила, Алексея и Василия Прокопьевичей Медведниковых и Анны Прокопьевны, в замужестве Мичуриной. Вместе со старшим братом в Москву в начале 1850-х гг. перебрался и Логин Логинович Медведников. В начале 1890-х гг. его сын Иван служил в Московской конторе Государственного банка ${ }^{59}$.

1 сентября 1889 г. Иван Логинович Медведников скончался и был захоронен на территории московского Спасо-Андроникова монастыря. Согласно немногочисленным свидетельствам, оставшись вдовою, Александра Ксенофонтовна «повела жизнь еще более уединенную» ${ }^{60}$. Значительную часть времени занимало начатое ею в середине $1890-$ х гг. строительство богадельни для лиц разных сословий, приюта для бедных престарелых священнослужителей Московской епархии и при нем церкви во имя Казанской иконы Божией Матери. Для организации богадельни и приюта А.К. Медведниковой в пользу Московской епархии было передано имение в с. Поречье с принадлежащей ей землей, усадебным домом и другими строениями, а также капитал в 400 тыс. руб. ${ }^{61}$

Более 200 тыс. руб. выделила она на строительство Казанской церкви. Здание храма с высоким восьмигранным барабаном и шатровым завершением было выстроено по проекту епархиального архитектора С.В. Крыгина, внутренняя отделка выполнена молодым архитектором И.С. Кузнецовым. Интерьеры церкви выглядели богато: «Иконостасы, подоконники и полы мраморные, престолы и жертвенники серебряные, напрестольные предметы и священные сосуды - серебряные, церковная утварь из бронзы высшего качества, облачения - из дорогой золотой и серебряной парчи. В этот же храм поступали и все домовые иконы Медведниковых» ${ }^{62}$. Желая на месте следить за качеством выполняемых работ, А.К. Медведникова в мае 1899 г. переехала на постоянное жительство в Поречье, заняв небольшой флигель рядом со строящейся церковью ${ }^{63}$. Строительство храма заняло несколько лет, в начале XX в. он был освящен (утрачен в 1930-е гг.).

Значительное состояние, принадлежащее лично А.К. Медведниковой и перешедшее ей после смерти мужа, требовало распределения. В течение 1895 - начале 1896 г. Александрой Ксенофонтовной было составлено завещание. Имеющиеся факты позволяют рассматривать его как результат взвешенного, продуманного решения. В соответствии с общей волей жертвовательницы, отразившей, прежде всего, ее глубокую религиозность («содействовать благолепию церковных храмов и облегчить участь сирых, убогих, немощных и прочих

\footnotetext{
${ }_{58}$ Ульянова Г.Н. Благотворительность в Российской империи... С. 363-364.

${ }^{59}$ ГАИО. Ф. 156. Оп. 1. Д. 182. Л. 66-66 об.

${ }^{60}$ Памяти умершей благотворительницы... С. 541.

${ }^{61}$ Там же. С. 542.

${ }^{62}$ Там же.

${ }^{63}$ Там же.
} 
нуждающихся» $\left.{ }^{64}\right), 600$ тыс. руб. были завещаны Иркутску на устройство и содержание «богадельни на 60 человек с церковью и причтом», ремонт городской больницы и пособия беднейшим жителям города ${ }^{65}$. Интересно отметить, что А.К. Медведникова посчитала необходимым поставить в известность о своем решении иркутян. Нестандартность ситуации выразилась в активных попытках Иркутской городской управы изменить назначение завещаемых капиталов. В письме в Иркутск от 14 января 1898 г. А.К. Медведникова сообщала: «Убедившись из личных переговоров с городским головой Владимиром Платоновичем Сукачевым в крайней необходимости скорейшего устройства больницы в Иркутске, я решилась исполнить означенные завещательные распоряжения теперь же и потому просила его возвратить мне мое прежнее заявление о постройке богадельни, обещая по получении означенного заявления внести в Московскую контору Госбанка на хранение на имя Иркутского городского общественного управления свидетельства гос. $4 \%$ ренты на сумму 600000 рублей» $^{66}$. Данный случай стал одним из немногих примеров тесного взаимодействия жертвователя с органами городского самоуправления по вопросам назначения завещаемых капиталов. Согласно воле А.К. Медведниковой был выработан Устав будущей больницы для хроников, принятый 26 февраля 1898 г. ${ }^{67}$

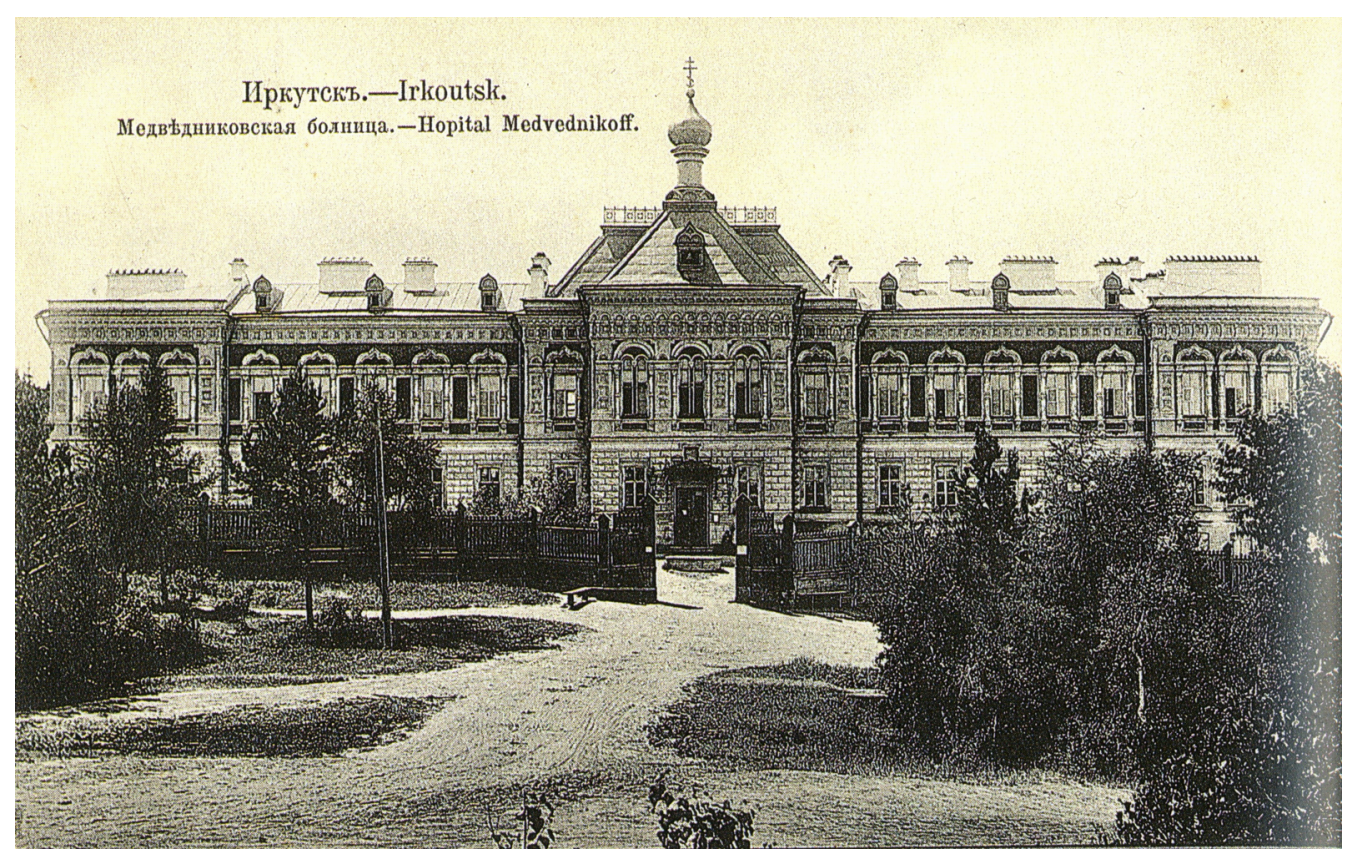

Иркутск. Медведниковская больница. Почтовая открытка. Начало ХХ 8.

Строительство подобной больницы являлось настоятельной необходимостью для города. Как отмечалось на заседании Иркутской городской думы, «положение хронических больных в городе поистине ужасно: они не могут быть приняты, и действительно не принимаются ни в одну из обыкновенных больниц. В существующие в Иркутске богадельни они также не принимаются как по недостатку в них свободных мест, так равно и по причине их болезненного состояния, требующего не только призрения, но и специального лечения, тщательного надзора и ухода. Между тем, число таких бедняков в городе очень значительно» ${ }^{68}$.

Высоко оценивая значение столь щедрого пожертвования, Иркутская городская дума на заседании 13 мая 1898 г. единогласно приняла решение о присвоении Александре Ксенофонтовне Медведниковой звания почетной гражданки города Иркутска ${ }^{69}$. Она стала

\footnotetext{
${ }^{64}$ ГАИО. Ф. 156. ОП. 1. Д. 239. Л. Зоб.

${ }^{65}$ Романов Н.С. Летопись города Иркутска за 1881-1901 гг. Иркутск, 1993. С. 344.

${ }^{66}$ Известия Иркутской городской думы. 1898. № 3-4. С. 106-107.

${ }^{67}$ Там же. № 5-6. С. 191-195.

${ }^{68}$ Там же. № 20. С. 276.

${ }^{69}$ Там же. 1899. № 11-12. C. 108-109.
} 
первой женщиной в Иркутске, удостоенной этой высокой награды. Портрет А.К. Медведниковой решено было вывесить в зале заседаний думы, а портреты И.Л. и А.К. Медведниковых разместить в больнице их имени. Каменное здание Медведниковской больницы для хроников было построено в 1901 г. (архитектор А.И. Кузнецов). Больница, одна из немногих в городе, имела собственный капитал, дающий около 1 тыс. руб. в год, обеспечивая ей устойчивое независимое состояние. Город в расходах на содержание лечебницы участия не принимал.

Основная часть капиталов, указанных в нотариально заверенном 20 мая 1896 г. завещании (всего более 5 млн руб.) передавалась Московскому городскому общественному управлению. Поддержка именно муниципальных подведомственных институтов помощи, выбранных из всего спектра разнообразных видов помощи и типов заведений, как отмечает Г.Н. Ульянова, являлась характерной особенностью развития благотворительности на рубеже XIX-XX вв., свидетельствуя о росте «гражданского отклика отдельных личностей или групп лиц на животрепещущие проблемы городской жизни» ${ }^{70}$.

Интересно отметить, что назначение жертвуемых А.К. Медведниковой капиталов Иркутску и Москве имело ряд общих векторов. Оба города получили по 100 тыс. руб. «в пользу бедных жителей христианского вероисповедания без различий пола и званий». В столице проценты с данного капитала, составлявшие ежегодную сумму в 5 тыс. руб., раздавались подавшим заявление о бедности в городскую думу трижды в год: на Пасху и в дни памяти И.Л. и А.К. Медведниковых ${ }^{71}$. Аналогичным образом распределялись капиталы и в Иркутске.

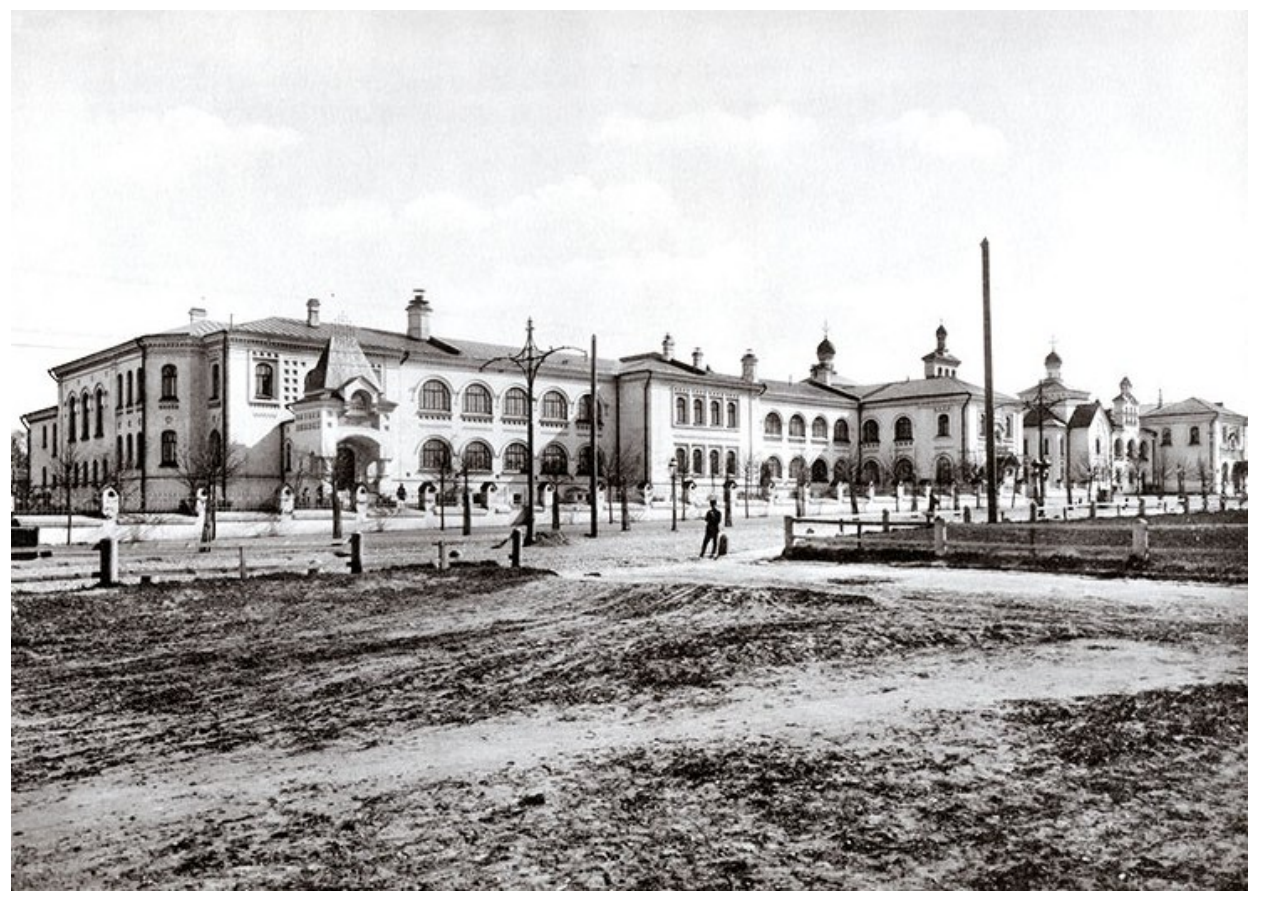

Благотворительный комплекс на Большой Калужской улище.

Москва. Фото начало ХХ в.

И в Москве, и в Иркутске по воле жертвовательницы предполагалось строительство больниц с домовыми церквями. В Иркутске - для хронически больных (500 тыс. руб. по завещанию), в Москве - для неизлечимо больных (1 млн руб. по завещанию, открыта на Большой Калужской улице в декабре 1903 г., архитектор С.У. Соловьев).

Из иных распределенных самой завещательницей капиталов, переданных Московскому городскому общественному управлению (2,04 млн руб.), 600 тыс. руб. предназначались на устройство и содержание приюта для идиотов и эпилептиков (открыт в 1914 г., передан под военный госпиталь); 300 тыс. руб. - на устройство и содержание богадельни, рассчитанной

\footnotetext{
${ }^{70}$ Ульянова Г.Н. Благотворительность в Российской империи... С. 360.

${ }^{71}$ Ульянова Г.Н. Благотворительность московских предпринимателей... С. 136.
} 
на 30 стариков и 30 старух, с Тихвинской церковью (1903 г., открыта на 68 кроватей). 25 тыс. руб. передавались больнице для душевно-больных за Серпуховскою заставою на Канатчиковой даче для содержания кроватей имени Александры Медведниковой $(1900 \text { г. })^{72}$; 15 тыс. руб. - на постройку здания мастерских в Алексеевской психиатрической больнице ${ }^{73}$.

Завещанные А.К. Медведниковой капиталы стали одним из крупнейших пожертвований среди столичного купечества. До 1917 г. только 10 представителей третьего сословия, как и А.К. Медведникова, передали более 1 млн руб. в пользу Московского городского общественного управления (А.В. Алексеева, В.А. и А.А. Бахрушины, Н.И. Боев, Ф.Я. Ермаков, А.И. Коншина, К.Т. Солдатенков, Г.Г. Солодовников, К.В. Третьяков, П.М. Третьяков $)^{74}$. Мотивы столь гигантских пожертвований купечеством были в значительной степени связаны с его глубокой религиозностью, с одной стороны, а также бездетностью, с другой ${ }^{75}$. Подобные установки благотворительности были присущи и А.К. Медведниковой.

Существенным фактором, обусловившим наличие среди крупных благотворителей значительной доли женщин, являлось российское семейно-брачное законодательство, предусматривающее самостоятельное распоряжение имуществом женщины. «Купчихи могли располагать большими капиталами и распоряжаться ими по своему усмотрению» ${ }^{76}$. Среди других крупных пожертвований по завещанию, но не связанных с Московским городским общественным управлением, Александрой Ксенофонтовной было выделено 50 тыс. руб. Московскому университету на учреждение стипендии имени Ивана и Александры Медведниковых, 50 тыс. руб. (по 10 тыс. руб.) - пяти московским приютам, попечительствам и обществам; 160 тыс. руб. - «на вечное поминовение» 16-ти монастырям; 39 тыс. руб. - различным церквям и монастырям; 10 тыс. руб. - в пользу приходской Предтеченской церкви. По 100 руб. передавалось «всем без исключения православным церквям в Москве и Иркутске на годовое поминовение завещательницы». Интересно отметить упоминание Александрой Ксенофонтовной в завещании о. Иоанна Кронштадтского, что являлось косвенным свидетельством их возможного знакомства: 3 тыс. руб. А.К. Медведникова передавала «о. Иоанну Ильичу Сергиеву в Кронштадт на вечное поминовение ее и близких родственников» ${ }^{77}$.

Весь остальной капитал, после покрытия всех расходов по утверждению и исполнению завещания, предполагалось употребить «ее душеприказчиком на устройство и поддержание церквей, школ, амбулаторных пунктов, больниц, богаделен, на стипендии в учебных заведениях, в пользу переселенцев и на другие благотворительные дела по его личному усмотрению» ${ }^{78}$.

23 ноября 1899 г. в возрасте 85 лет Александра Ксенофонтовна скончалась и была погребена в устроенной ею Казанской церкви с. Поречья около левого клироса главного престола в приготовленном склепе. Надгробие было выполнено архитектором И.С. Кузнецовым (могила в 1930-х гг. была утеряна).

14 декабря 1899 г. в Московском окружном суде было заслушано дело об утверждении к исполнению нотариального духовного завещания вдовы коммерции советника А.К. Медведниковой ${ }^{79}$, а с 15 января 1900 г. в московском доме А.К. Медведниковой ее душеприказчиком Н.А. Цветковым открылась контора для приема и разбора прошений о пособии из капитала, оставленного в его распоряжение. Как сообщала газета «Церковные

\footnotetext{
72 Памяти умершей благотворительницы... С. 542.

73 Ульянова Г.Н. Благотворительность московских предпринимателей... С. 371.

${ }^{74}$ Там же. С. 198.

${ }^{75}$ Там же. С. $200-201$.

${ }^{76}$ Там же. С. 347-349.

${ }^{77}$ Памяти умершей благотворительницы... С. 543.

${ }^{78}$ Там же.

${ }^{79}$ ГАИО. Ф. 156. Оп. 1. Д. 239. Л. 3.
} 
ведомости», «таковых прошений со всех концов России к концу марта поступило более 10 тысяч» $^{80}$.

К чести душеприказчика А.К. Медведниковой Н.А. Цветкова завещанные капиталы были распределены по назначению, а подавляющая часть остальных средств по его решению была направлена на строительство и содержание гимназии. Газета «Сибирская жизнь» в 1901 г. писала: «В Москве недавно открылась новая гимназия имени И. и А. Медведниковых [...]. Циркуляр бывшего министра народного просвещения Н.П. Боголепова, посвященный вопросу о недостатках средней школы, приковал к себе внимание всего русского общества [...]. В это время [...] зародилась среди группы московских педагогов мысль о новой гимназии. Н.А. Цветков пошел на встречу этому предложению, изъявив готовность предоставить на это дело необходимые средства» ${ }^{81}$.

Первое время Медведниковская гимназия проводила занятия в доме на ул. Поварской, а с 1904 г. - в собственном здании в Староконюшенном переулке (архитектор И.С. Кузнецов). Она стала, по сути, первой в России средней общеобразовательной школой. Заслуга в этом в определенной степени принадлежала учредителю гимназии - душеприказчику А.К. Медведниковой

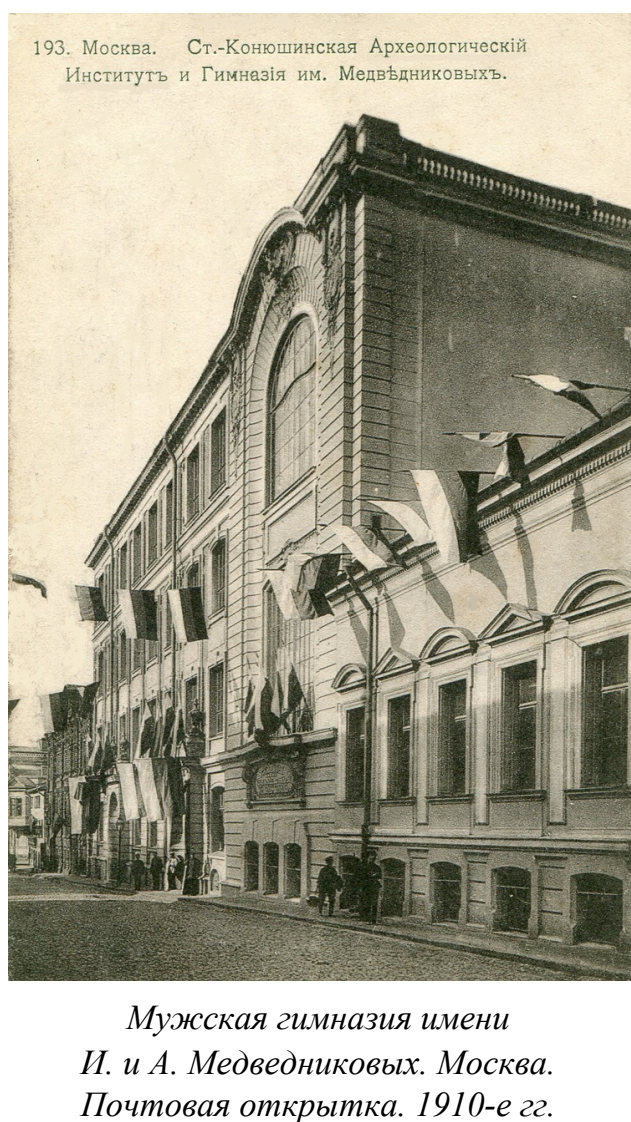
Н.А. Цветкову.

Последовавшая в 1900-1910-х гг. реализация завещанных А.К. Медведниковой капиталов и все более широкое обнародование сумм завещанных ею пожертвований способствовали общественному признанию ее заслуг. Вскоре о ней заговорили как об «одной из крупных российских благотворительниц» Москвы и Иркутска, тем более, что на 1880-1890-е гг. пришлась серия значительных пожертвований благотворительниц из купеческого сословия Иркутска.

Таким образом, с точки зрения поколенческих характеристик жертвовательниц период 1880-1890-х гг. совместил, с одной стороны, пик благотворительной активности представительниц купеческого сословия младшего поколения (родившихся в 1840-1850-е гг.), a c другой - пожертвования по завещанию, своеобразный «итоговый этап» благотворительной деятельности старшей возрастной когорты женщин-благотворительниц купеческого сословия (родившихся в 1810-1820-е гг.). Наиболее яркой представительницей последних, реализовавшей типичную для ее поколения модель «женской благотворительности», и стала А.К. Медведникова.

\section{Лumepamypa}

Бойко В.П. Купечество Западной Сибири в конце XVIII-XIX в.: Очерки социальной, отраслевой и ментальной истории. Томск: Изд-во Том. гос. архит.-строит. ун-та, 2009. 308 с.

Душкин Ю. «...от корабельного морского ходу» // Литературный Иркутск. 1989. Март. C. $14-15$.

\footnotetext{
${ }^{80}$ Памяти умершей благотворительницы... С. 544.

${ }^{81}$ Гимназия Медведниковых // Сибирская жизнь. 1901. № 225. С. 3.
} 
Зуева Е.А., Гаврилова Н.И. Медведниковы // Энциклопедический словарь по истории купечества и коммерции Сибири. Новосибирск: Академическое издательство «Гео», 2013. T. 2. C. 36-38.

Комлева E.B. «Тузы-капиталисты»: образ сибирского купца в региональной периодической печати второй половины XIX в. // Известия Иркутского государственного университета. Серия: «История». 2018. Т. 24. С. 36-45.

Кротов В.А. Летопись города Иркутска. 1652-1856 гг. Иркутск: Сибирская книга, 2013. $448 \mathrm{c}$.

Манассеин В.С. Сибирский библиофил В.Н. Баснин и его библиотека (первая половина XIX-го ст.). Иркутск, [б. г.]. Фонд Научной библиотеки Иркутского государственного университета. Рукопись № 397.

Мартос А. Письма из Восточной Сибири. М.: В Университетской тип., 1827. 291 с.

Милютин Б.А. Генерал-губернаторство Н.Н. Муравьева-Амурского в Сибири // Исторический вестник. 1888. Т. 34. № 11. С. 317-364; № 12. С. 595-635.

Очерки историографии Сибири эпохи империи (XVIII - начало XX века) / Л.М. Дамешек, И.Л. Дамешек, В.П. Шахеров, А.С. Маджаров, Т.А. Перцева. Иркутск: Изд-во ИГУ, 2017. $261 \mathrm{c}$.

Памяти умершей благотворительницы Александры Ксенофонтовны Медведниковой // Церковные ведомости, издаваемые при Святейшем Правительствующем Синоде. 1900. № 13. 25 марта. С. 541-544.

Поджио А.В. Записки, письма / издание подготовлено Н.П. Матхановой. Иркутск: Вост.Сиб. кн. изд-во, 1989. 592 с.

Попов И.И. Забытые иркутские страницы. Записки редактора. Иркутск: Вост.-Сиб. кн. изд-во, $1989.384 \mathrm{c.}$

Полное собрание законов Российской Империи. Собр. 2. СПб., 1833. Т. ХІ.

Романов Н.С. Летопись города Иркутска за 1881-1901 гг. Иркутск: Вост.-Сиб. кн. изд-во, 1993. $543 \mathrm{c.}$

Скубневский B.A. Благотворительность предпринимателей Алтая во второй половине XIX - начале XX в. // Вестник Томского государственного университета. 2018. № 435. C. $155-160$.

Сабиньский Ю.Г. Сибирский дневник: в 2 т. Т. 2. Иркутск: Иркутский музей декабристов: Артиздат, 2015. $840 \mathrm{c.}$

Ульянова Г.Н. Благотворительность в Российской империи, XIX - начало XX века. М.: Наука, 2005. 403 с.

Ульянова Г.Н. Благотворительность московских предпринимателей. 1860-1914. Словарь купцов-благотворителей. М.: ФОРУМ; НЕОЛИТ, 2014. 496 с.

Чижков А.Б. Подмосковные усадьбы сегодня: Путеводитель с картой-схемой. М.: ОАИРО-ХХ, 2000. $256 \mathrm{c.}$

Шахеров В.П. Иркутск купеческий. История города в лицах и судьбах. Хабаровск: Приамурские ведомости, 2006. 176 с.

Шахеров В.П. Социокультурные процессы в городской среде Байкальской Сибири XVIII первой половине XIX в. Иркутск: Изд-во ИГУ, 2013. 256 с.

\section{References}

Boyko,V.P. (2009). Kupechestvo Zapadnoy Sibiri v kontse XVIII-XIX v.: Ocherki sotsialnoy, otraslevoy $i$ mentalnoy istorii [The merchants of Western Siberia in the late XVIII-XIX centuries : Essays on the social, industrial and mental history]. Tomsk, Izd-vo TGASU. 308 p.

Dushkin, Yu. (1989). “...ot korabel'nogo morskogo khodu” [“...starting with ships"]. In Literaturnyi Irkutsk. Mart, pp. 14-15.

Zueva, E.A., Gavrilova, N.I. (2013), "Medvednikov", In Entsiklopedicheskii slovar po istorii kupechestva i kommertsii Sibiri. Novosibirsk, Akademicheskoye izd-vo “Geo”. Vol. 2, pp. 36-38. 
Komleva, E.V. (2018). “Tuzi-kapitalisti”: obraz sibirskogo kuptsa v regional'noy periodicheskoy pechati vtoroy polovini XIX v. ["Heavyweght Capitalists": Image of Siberian Merchant in the Regional Periodicals of the Second Half of the XIX Century]. In Izvestiya Irkutskogo Gosudarstvennogo universiteta. Seriya: Istoriya. Vol. 24, pp.36-45.

Krotov, V.A. (2013). Letopis goroda Irkutska. 1652-1856 gg. [Chronicle of Irkutsk. 16521856]. Irkutsk, Sibirskaya kniga. 448 p.

Manassein, V.S. Sibirskiy bibliofil V.N. Basnin i ego biblioteka (pervaya polovina XIX-go st.) [Siberian bibliophile V.N. Basnin and his library (first half of the XIX century)], Manuscript № 397. Irkutsk, Fond of Scientific library of Irkutsk State University.

Martos, A. (1827). Pis'ma iz Vostochnoy Sibiri [Letters from Eastern Siberia]. Moscow, V Universitetskoy tip. $291 \mathrm{p}$.

Milytin, B.A. (1888). General-gubernatorstvo N.N. Murav'eva-Amurskogo v Sibiri [GovernorGeneral N.N. Muravyov-Amursky in Siberia]. In Istoricheskiy vestnik. Vol. 34. No. 11, pp. 317364; No. 12. pp. 595-635.

Dameshek, L.M. (Ed.). (2017). Ocherki istoriografii Sibiri epokhi imperii (XVIII - nachalo XX veka) [Essays on the historiography of Siberia in the era of the Empire (XVIII - early XX century)]. Irkutsk, Izd-vo IGU. 261 p.

Pamyati umershey blagotvoritel'nitsi Aleksandri Ksenofontovni Medvednikovoy [To the memory of the deceased philanthropist Alexandra Ksenofontova Medvednikova]. (1900). In Tserkovnyye vedomosti, izdavayemyye pri Svyateishem Pravitelstvuyushchem Sinode. No. 13. March, 25. pp. 541-544.

Poggio, A.V. (1989), Zapiski, pis'ma [Notes, letters / the publication was prepared by N.P. Matkhanova]. Irkutsk, Vost.-Sib. kn. Izd.-vo. 592 p.

Popov, I.I. (1989). Zabytyye irkutskiye stranitsy. Zapiski redaktora [Forgotten Irkutsk pages. Editor's notes]. Irkutsk, Vost.-Sib. kn. Izd.-vo. 384 p.

Polnoye Sobraniye Zakonov Rossiyskoy Imperii : Sobraniye vtoroye [Full collection of laws of the Russian Empire. Collection 2] (1837). Saint-Petersburg, Tipografiya 2-go Otdeleniya Sobstvennoy E.I.V. Kantselyarii, Vol. 11. Department 1: № 8739-9493. 902 p.

Romanov, N.S. (1993). Letopis' goroda Irkutska za 1881-1901 gg. [The Irkutsk city chronicle in 1881-1901]. Irkutsk, Irkutsk, Vost.-Sib. kn. Izd.-vo. 543 p.

Skubnevskiy, V.A. (2018). Blagotvoritel'nost' predprinimateley Altaya vo vtoroy polovine XIXnachale $X X v$. [Charity work of Altai merchants in the second half of the $19^{\text {th }}$ - early $20^{\text {th }}$ centuries]. In Vestnik Tomskogo gosudarstvennogo universiteta. No. 435. pp. 155-160.

Zabinsky, Ju.G. (2015). Sibirskiy dnevnik: $v 2 t$. [Siberian diary: in 2 vol.]. Irkutsk, Artizdat. Vol. 2. 840 p.

Ulyanova, G.N. (2005). Blagotvoritelnost'v Rossiiskoy imperii. XIX-nachalo XX veka [Charity in the Russian Empire, XIX - early XX century], Nauka, Moscow, Russia, 403 p.

Ulyanova, G.N. (2014). Blagotvoritelnost moskovskikh predprinimatelei. 1860-1914. Slovar kuptsov-blagotvoriteley [Charity work of Moscow merchants. 1860-1914. Dictionary of merchantsbenefactors], Moscow, FORUM, NEOLIT. 496 p.

Chirkov, A.B. (2000). Podmoskovnyye usadby segodnya: Putevoditel s kartoy-skhemoy [Moscow Suburban Estates Today: Guide with Map-Scheme]. Moscow, OAIRO-XX. 256 p.

Shakherov, V.P. (2006). Irkutsk kupecheskiy. Istoriya goroda V litsakh i sudbakh [The merchant's Irkutsk. The history of the city in persons and destinies]. In Priamurskie Vedomosti. Khabarovsk. 176 p.

Shakherov, V.P. (2013). Sotsiokulturnye protsessy v gorodskoy srede Baikalskoy Sibiri XVIII pervoy polovine $X I X v$. [Socio-cultural processes in the urban environment of Baikal Siberia in the XVIII - first half of the XIX century]. Irkutsk, Izd-vo IrGU 256 p.

Статья поступила в редакиию 30.01.2019 г. 